\title{
PREVALENCE OF PSEUDOEXFOLIATION SYNDROME AND PSEUDOEXFOLIATION GLAUCOMA IN POPULATION OF NORTH-WEST CROATIA AGED 40 AND OVER
}

\author{
Jasna Pavičić-Astaloš ${ }^{1}$, Ana Koluder ${ }^{1}$, Lana Knežević ${ }^{1}$, Mia Zorić Geber ${ }^{2}$,

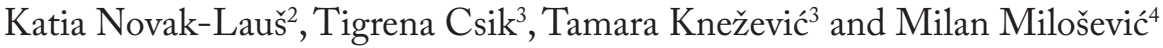 \\ ${ }^{1}$ Department of Ophthalmology, Dr Tomislav Bardek General Hospital, Koprivnica; \\ ${ }^{2}$ University Department of Ophthalmology, Sestre milosrdnice University Hospital Center; \\ ${ }^{3}$ Ghetaldus Polyclinic; ${ }^{4}$ Andrija Štampar School of Public Health, School of Medicine, \\ University of Zagreb, Zagreb, Croatia
}

\begin{abstract}
SUMMARY - The purpose of this study was to assess the prevalence of pseudoexfoliation syndrome and pseudoexfoliation glaucoma and to evaluate its association with open-angle glaucoma in patients attending the Department of Ophthalmology, Dr Tomislav Bardek General Hospital in Koprivnica, northwestern Croatia. This prospective study was conducted at Dr Tomislav Bardek General Hospital between December 2012 and October 2013. A total of 5349 subjects aged 40 or above presenting for general ophthalmic examination were screened for pseudoexfoliation syndrome and pseudoexfoliation glaucoma. Each patient underwent complete ophthalmologic examination including ocular history, visual acuity testing, slit-lamp examination, applanation tonometry, optic disc evaluation, visual field analysis, and gonioscopy if glaucoma was suspected. Exclusion criteria were pseudophakic and/or aphakic patients of any age, patients with concomitant congenital eye disease, and patients with very dense ocular media opacities. Out of 5349 patients examined, there were 1994 (38.38\%) males and 3201 (61.61\%) females. The prevalence of pseudoexfoliation syndrome was 3.6\% and primary open angle glaucoma $9.4 \%$, out of which $23.6 \%$ with pseudoexfoliation glaucoma. The findings of this study improve our knowledge of pseudoexfoliation syndrome and pseudoexfoliation glaucoma in Croatia, particularly in the northwest region.
\end{abstract}

Key words: Exfoliatiation syndrome - epidemiology; Prevalence; Elderly; Glaucoma

\section{Introduction}

Pseudoexfoliation syndrome (PXS) is an aging-related systemic disease with cardiovascular and cerebrovascular morbidity ${ }^{1-3}$ and hearing loss $s^{4,5}$ but only ocular manifestations. It is the single most important risk factor for glaucoma worldwide and a major factor predicting glaucoma progression ${ }^{6}$. The reported preva-

Correspondence to: Jasna Pavičic-Astaloš, $M D, P h D$, Department of Ophthalmology, Dr Tomislav Bardek General Hospital, Selingerova bb, HR-48000 Koprivnica, Croatia

E-mail: jpastalos@gmail.com

Received August 10, 2015, accepted March 30, 2016 lence of PXS varies extensively in different population-based studies from $4.0 \%$ in England, $4.7 \%$ in Germany, 6.3\% in Norway ${ }^{7}, 23 \%$ in northern Sweden ${ }^{8}$, $1.81 \%$ in Pakistan $9,1.49 \%$ in India ${ }^{10}, 10.7 \%$ in Iceland $^{11}, 16.1 \%$ in Crete (Greece) $)^{12}, 26 \%$ in the Bantu of South Africa ${ }^{13}, 7.10 \%$ in South Kashmir ${ }^{14}, 12.2 \%$ in Anatolia (Turkey) ${ }^{15}, 25.5 \%$ in Estonia ${ }^{16}$ and $6.5 \%$ in Spain ${ }^{17}$. Even within a country, the prevalence varies from one region to another because of different types of patient groups examined, therefore many results are incomparable.

The incidence of PXS roughly doubles each decade of life after the age of $50^{18}$. Since PXS has been linked 
to multiple pathological entities of the eye including glaucoma, cataract, perioperative complications during eye surgery ${ }^{19-24}$ and postoperative complications after cataract surgery ${ }^{25}$, it is of utmost importance to recognize ocular manifestations of PXS. Pseudoexfoliation $(\mathrm{PEX})$ at baseline was identified as an independent risk factor for primary open-angle glaucoma (POAG) and relation between increased intraocular pressure (IOP) and PXS was established in different studies ${ }^{26,27}$, suggesting obstruction of the aqueous humor outflow. Exposure to PXS and a mean IOP $\geq 25 \mathrm{~mm} \mathrm{Hg}$ increases the risk of POAG 56-fold ${ }^{28}$, indicating a high prevalence of POAG in a population with a high prevalence of PXS. POAG in PXS has been shown to have a more serious clinical course than POAG without $\mathrm{PXS}^{29}$. Higher age, positive family history ${ }^{30,31}$, high myopia, increased IOP together with PXS have been associated with a higher incidence of POAG. With the increasing number of elderly in the population, an increase of POAG and pseudoexfoliation glaucoma $(\mathrm{PXG})$ is expected in the future.

The prevalence of POAG, PXS and PXG in northwest Croatia is unknown and has never been analyzed before. According to data of the Association of the Blind and Visually Impaired of Northwest Croatia, $25 \%$ of blindnes cases are caused by glaucoma.

\section{Patients and Methods}

This hospital based prospective study was carried out at the Department of Ophthalmology, Dr Tomislav Bardek General Hospital in Koprivnica, northwest Croatia, from December 2012 to October 2013. The study was carried out in adherence to the tenets of the Declaration of Helsinki. The study protocol was reviewed and approved by the Ethics Committee of Dr Tomislav Bardek General Hospital.

The inclusion criterion was age $\geq 40$ in all patients presenting to the Ophthalmology Polyclinic for various ocular problems. Exclusion criteria were pseudophakic and/or aphakic patients of any age, patiens with dense ocular media opacities, and patients with concomitant congenital eye disease. A total of $5349 \mathrm{pa}^{-}$ tients aged $\geq 40$ were examined and screened for PXS and PXG. All patients underwent detailed ophthalmologic examination including ocular history, visual acuity testing, slit-lamp biomicroscopy for evidence of pseudoexfoliatory material on the edge of the pupil or lens, applanation tonometry and indirect funduscopy. In patients suspected of glaucoma and/or diagnosed with PXS, an additional examination was carried out including gonioscopy and visual field testing. Functional glaucoma testing was used to diagnose PXG, considering that at the time of the study optical coherence tomography device was not available, although it is an inevitable structural diagnostic tool required for detecting early structural optic nerve head changes.

The criteria for glaucoma suspected group were IOP $\geq 23 \mathrm{~mm} \mathrm{Hg}$, focal glaucomatous disc change (disc hemorrhage, notch of the neuroretinal rim, marked sloping of the rim tissue, narrowest remaining rim of 0.1 disc diameter or less), cup to disc ratio asymmetry $(\geq 0.3)$ and vertical cup to disc ratio $(>0.8)$. The criterion used to diagnose PXS was the presence of pseudoexfoliatory material on one or more anterior segment structures. The criterion for diagnosing PXG was the presence of pseudoexfoliatory material on one or more anterior segment structures with or without raised IOP in the presence of visual field defects compatible with glaucoma. The $\chi^{2}$-test was used to assess differences in the prevalence of different glaucoma related diagnoses according to age, gender and PXS groups. Furthermore, $\chi^{2}$-test was used in the analysis of PEX prevalence differences according to age and gender. All p values below 0.05 were considered statistically significant. MedCalc Statistical Software version 13.0 (MedCalc Software bvba, Ostend, Belgium; http://www.medcalc.org; 2014) was used in all statistical procedures.

\section{Results}

Out of 5349 patients examined, there were 1994 (38.38\%) males and 3201 (61.61\%) females. Distribution of patients according to age groups is shown in Table 1 . Study patients were classified into groups as follows: 1) healthy subjects without glaucoma (WG); 2) glaucoma suspected group (GSG); 3) primary open-angle glaucoma (POAG); 4) primary angle-closure glaucoma (PACG); and 5) secondary glaucoma (SG).

Differences in the prevalence of various glaucoma related diagnoses in study patients according to gender are shown in Table 2. Only one significant difference was noted, i.e. PACG was more prevalent in female gender as compared with male gender $(4.81 \%$ vs. 
Table 1. Distribution of patients according to age groups

\begin{tabular}{|l|c|c|c|c|c|}
\hline \multirow{2}{*}{} & \multicolumn{4}{|c|}{ Age group (yrs) } & \multirow{2}{*}{ Total } \\
\cline { 2 - 6 } & $40-49$ & $50-59$ & $60-69$ & $\geq 70$ & \\
\hline $\begin{array}{l}\text { Number } \\
\text { of patients }\end{array}$ & 705 & 1370 & 1287 & 1987 & 5349 \\
\hline
\end{tabular}

Table 2. Gender difference in the prevalence of different glaucoma related diagnoses $\left(\chi^{2}\right.$-test)

\begin{tabular}{|c|l|c|c|c|c|c|}
\hline \multirow{2}{*}{} & \multicolumn{3}{|c|}{ Gender } & \multirow{2}{*}{} \\
\cline { 3 - 6 } & \multicolumn{2}{|c|}{ Male } & \multicolumn{2}{c|}{ Female } & \multirow{2}{*}{$\mathrm{p}$} \\
\cline { 2 - 6 } & $\mathrm{N}=1994$ & \multicolumn{2}{c}{$\mathrm{N}=3201$} & \\
\cline { 2 - 6 } Group & $\mathrm{n}$ & $\%$ & $\mathrm{n}$ & $\%$ & \\
\hline \multirow{5}{*}{} & WG & 1689 & $84.7 \%$ & 2680 & $83.7 \%$ & 0.368 \\
& GSG & 80 & $4.0 \%$ & 154 & $4.8 \%$ & 0.199 \\
& POAG & 191 & $9.6 \%$ & 297 & $9.3 \%$ & 0.755 \\
& PACG & 7 & $0.4 \%$ & 38 & $1.2 \%$ & 0.003 \\
& SG & 27 & $1.4 \%$ & 32 & $1.0 \%$ & 0.306 \\
\hline
\end{tabular}

$\mathrm{WG}=$ without glaucoma; GSG = glaucoma suspected group; $\mathrm{POAG}=$ primary open-angle glaucoma PACG $=$ primary angleclosure glaucoma; $\mathrm{SG}=$ secondary glaucoma
4.01\%, $\mathrm{p}=0.003$ ). All other glaucoma diagnoses were equally distributed in both genders. Age difference in the prevalence of various glaucoma related diagnoses showed that glaucoma suspected diagnosis, POAG and PACG were significantly more prevalent among older patients $(\mathrm{p}<0.001)$. Patients without glaucoma disease were significantly more prevalent in younger age groups (Table 3). Differences in the prevalence of POAG according to age groups are shown in Table 4. Age-specific prevalence distribution in POAG group showed an increase from $2 \%$ in the $40-49$ age group to $67.9 \%$ in the $\geq 70$ age group.

A total of 5349 patients were examined for PXS and PXG. The prevalence of PXS was $3.6 \%$ and of POAG 9.4\%, of which $23.6 \%$ of cases had PXG. Age and gender differences in the prevalence of PXS are shown in Table 5. PXS was significantly more prevalent in older age groups; more than $80 \%$ of patients with PXS were over 70 years of age $(p<0.001)$. There was no significant gender difference $(\mathrm{p}=0.121)$.

Table 6 shows differences in the prevalence of PXS according to particular diagnoses. The most prominent

Table 3. Age difference in the prevalence of various glaucoma related diagnoses $\left(\chi^{2}\right.$-test)

\begin{tabular}{|c|c|c|c|c|c|c|c|c|c|c|}
\hline & \multicolumn{8}{|c|}{ Age group (yrs) } & \multirow{4}{*}{$\mathrm{p}$} \\
\hline & & \multirow{2}{*}{\multicolumn{2}{|c|}{$\begin{array}{l}45-49 \\
\mathrm{~N}=705\end{array}$}} & \multirow{2}{*}{\multicolumn{2}{|c|}{$\begin{array}{c}50-59 \\
\mathrm{~N}=1370 \\
\end{array}$}} & \multirow{2}{*}{\multicolumn{2}{|c|}{$\begin{array}{c}60-69 \\
N=1287\end{array}$}} & \multirow{2}{*}{\multicolumn{2}{|c|}{$\begin{array}{c}\geq 70 \\
\mathrm{~N}=1987\end{array}$}} & \\
\hline & & & & & & & & & & \\
\hline & & $\mathrm{n}$ & $\%$ & $\mathrm{n}$ & $\%$ & $\mathrm{n}$ & $\%$ & $\mathrm{n}$ & $\%$ & \\
\hline \multirow{5}{*}{ Group } & WG & 674 & $95.6 \%$ & 1260 & $92.0 \%$ & 1091 & $84.8 \%$ & 1473 & $74.1 \%$ & $<0.001$ \\
\hline & GSG & 16 & $2.3 \%$ & 49 & $3.6 \%$ & 64 & $5.0 \%$ & 111 & $5.6 \%$ & $<0.001$ \\
\hline & POAG & 10 & $1.4 \%$ & 46 & $3.4 \%$ & 105 & $8.2 \%$ & 340 & $17.1 \%$ & $<0.001$ \\
\hline & PACG & 0 & $0.0 \%$ & 2 & $0.1 \%$ & 9 & $0.7 \%$ & 37 & $1.9 \%$ & $<0.001$ \\
\hline & SG & 5 & $0.7 \%$ & 13 & $0.9 \%$ & 18 & $1.4 \%$ & 26 & $1.3 \%$ & 0.422 \\
\hline
\end{tabular}

$\mathrm{WG}=$ without glaucoma; $\mathrm{GSG}=$ glaucoma suspected group; $\mathrm{POAG}=$ primary open-angle glaucoma $\mathrm{PACG}=$ primary angle-closure glaucoma; SG = secondary glaucoma

Table 4. Differences in primary open-angle glaucoma (POAG) prevalence according to age groups $\left(\chi^{2}\right.$-test)

\begin{tabular}{|c|c|c|c|}
\hline & \multicolumn{2}{|c|}{ POAG } \\
\hline & & $\mathrm{n}$ & $\%$ \\
\hline \multirow{4}{*}{$\begin{array}{l}\text { Age group } \\
\text { (yrs) }\end{array}$} & $40-49$ & 10 & $2.0 \%$ \\
\hline & 50-59 & 46 & $9.2 \%$ \\
\hline & 60-69 & 105 & $21.0 \%$ \\
\hline & $\geq 70$ & 340 & $67.9 \%$ \\
\hline$p<0.001$ & & & \\
\hline
\end{tabular}

differences were recorded in the GSG and POAG groups $(p<0.001)$. The prevalence of PXG in the PXS population was $63.3 \%$. The GSG patients also showed a high prevalence of PXS (31.4\%).

\section{Discussion}

Our study investigated the prevalence of PXS and PXG in northwest Croatia and their association with POAG. All our patients were Caucasians, which cor- 
Table 5. Age and gender differences in the prevalence of pseudoexfoliation syndrome (PXS) ( $\chi^{2}$-test)

\begin{tabular}{|c|c|c|c|c|c|c|}
\hline & \multicolumn{4}{|c|}{ PXS } & \multirow{3}{*}{$\mathrm{p}$} \\
\hline & & \multicolumn{2}{|c|}{$\mathrm{No}$} & \multicolumn{2}{|c|}{ Yes } & \\
\hline & & $\mathrm{n}$ & $\%$ & $\mathrm{n}$ & $\%$ & \\
\hline \multirow{4}{*}{$\begin{array}{l}\text { Age group } \\
\text { (years) }\end{array}$} & $45-49$ & 704 & $13.60 \%$ & 1 & $0.50 \%$ & \multirow{4}{*}{$<0.001$} \\
\hline & $50-59$ & 1363 & $26.40 \%$ & 7 & $3.70 \%$ & \\
\hline & $60-69$ & 1259 & $24.40 \%$ & 28 & $14.90 \%$ & \\
\hline & $\geq 70$ & 1835 & $35.60 \%$ & 152 & $80.90 \%$ & \\
\hline \multirow{2}{*}{ Gender } & Male & 1932 & $38.60 \%$ & 62 & $33.00 \%$ & \multirow{2}{*}{0.121} \\
\hline & Female & 3075 & $61.40 \%$ & 126 & $67.00 \%$ & \\
\hline
\end{tabular}

Table 6. Differences in PXS prevalence according to various diagnoses $\left(\chi^{2}\right.$-test)

\begin{tabular}{|c|l|c|c|c|c|c|}
\hline \multirow{2}{*}{} & \multicolumn{5}{|c|}{ PXS } & \multirow{2}{*}{} \\
\cline { 3 - 6 } & \multicolumn{3}{|c|}{ No } & \multicolumn{2}{c|}{ Yes } \\
\cline { 3 - 6 } & \multicolumn{2}{|c|}{$\mathrm{N}=5161$} & \multicolumn{2}{c|}{$\mathrm{N}=188$} & \\
\cline { 3 - 6 } Group & $\mathrm{n}$ & $\%$ & $\mathrm{n}$ & $\%$ & \\
\hline \multirow{6}{*}{} & WG & 4491 & $87.0 \%$ & 7 & $3.7 \%$ & $<0.001$ \\
& GSG & 181 & $3.5 \%$ & 59 & $31.4 \%$ & $<0.001$ \\
& POAG & 382 & $7.4 \%$ & 119 & $63.3 \%$ & $<0.001$ \\
& PACG & 46 & $0.9 \%$ & 2 & $1.1 \%$ & 0.88 \\
& SG & 61 & $1.2 \%$ & 1 & $0.5 \%$ & 0.637 \\
\hline
\end{tabular}

PXS = pseudoexfoliation syndrome; $\mathrm{WG}=$ without glaucoma; $\mathrm{GSG}=$ glaucoma suspected group; $\mathrm{POAG}=$ primary open-angle glaucoma; $\mathrm{PACG}$ = primary angle-closure glaucoma; $\mathrm{SG}=$ secondary glaucoma

responds to the demographic profile of the country. In our study, the overall prevalence of POAG was $9.4 \%$. Considering the studies of racial distribution and the highest prevalence of POAG in the black populations of all ages ${ }^{32,33}$, this region may be considered to be at low risk. Our results are comparable with data of previous studies ${ }^{34,35}$ concerning age differences in the prevalence of POAG. In our study, the age-specific prevalence distribution increased from $1.4 \%$ in the $40-$ 49 age group to $17.1 \%$ in the $\geq 70$ age group. In the study by Rudnicka et al., the proven age proportional increase in the prevalence of POAG with age was highest in white populations ${ }^{36}$. The odds ratio per decade increase in age was 2.3 in our population, which is comparable with the mentioned study. We found no gender differences in patients with POAG but in those with angle-closure glaucoma it was 3 times more prevalent in female gender. Similar data have also been reported from previous studies ${ }^{37,38}$. The study by Bojić et al. investigated the incidence of acute angle-closure glaucoma among residents of Dalmatia, the southern part of Croatia, and found the relative risk of developing acute angle-closure glaucoma to be 2.1 times higher in women as compared with men ${ }^{39,40}$. We found the prevalence of PACG to be $0.9 \%$. Such a low prevalence of PACG has been reported among Caucasians ${ }^{41}$.

In our study, the prevalence of GSG patients was $4.5 \%$. The GSG patients also showed a high prevalence of PXS. Such prevalence has previously been reported in the Reykjavik Eye Study ${ }^{42}$. The prevalence of PXS was $3.6 \%$. Analyzing the results from other European countries on the prevalence of $\mathrm{PXS}^{7,8,12,17}$, our results place the northwest Croatia population in the low risk group for PXS. We found no significant gender difference but only age related difference among patients with PXS. Other studies showed a higher prevalence of PXS in women ${ }^{8,11,43}$, but the study by Susić and Brajković conducted in the population of the southern part of Croatia revealed no significant gender difference in the prevalence of PXS either ${ }^{19}$. 
Pseudoexfoliation syndrome was significantly more prevalent in older age groups and more than $80 \%$ of PXS patients were over 70 years of age. Similar data have been reported before ${ }^{8,11,17,43}$. The increase in PXS was 66 times greater as compared with the 60-69 age group. A total of 119 (63.3\%) patients in the PXS group exhibited glaucoma, while in the non PXS group only $7.4 \%$ of patients suffered from glaucoma. These data confirmed the high prevalence of glaucoma in the population with PXS.

Given the aging of the population in Croatia ${ }^{44}$, further increase in PXS, PXG and POAG is expected in the future. Determination of the prevalence of glaucoma disease is important for each country in terms of healthcare planning and prevention of blindness, with particular reference to glaucoma disease and the elderly $^{45}$. The data on the prevalence of PXS and PXG recorded in this study are the first referring to the area of northwest Croatia. The benefit of this study is that it was the first such study performed in Croatia, especially considering the number of participants. Since we were unable to detect patients with preperimetric glaucoma because we could not use optical coherence tomography, we consider it a limitation of the study. Education of the population at large should be implemented, focusing on the importance of family history in all types of glaucoma ${ }^{30}$. To our knowledge, this was the first study conducted in the northwest Croatia population to determine the prevalence of PXS, PXG, POAG and PACG. This study provided data for future studies and monitoring of the prevalence of different types of glaucoma.

\section{References}

1. Demir N, Ulus T, Yucel OE, Kumral ET, Singar E, Tanboga HI. Assessment of myocardial ischaemia using tissue Doppler imaging in pseudoexfoliation syndrome. Eye. 2011;25:117780. http://dx.doi.org/10.1038/eye.2011.145

2. Brajković J,Kalauz-Surač I,Ercegović A,Miletić-Jurić A, Susić $\mathrm{N}$, Burić Z. Ocular pseudoexfoliation syndrome and internal systemic diseases. Acta Clin Croat. 2007;46(1):57-61.

3. Shrum KR, Hattenhauer MG, Hodge D. Cardiovascular and cerebrovascular mortality associated with ocular pseudoexfoliation. Am J Ophthalmol. 2000;82:401-4.

4. Yazdani S, Tousi A, Pakravan M, Faghihi AR. Sensorineural hearing loss in pseudoexfoliation syndrome. Ophthalmology. 2008;115:425-9.

5. Aydogan Ozkan B, Yuksel N, Keskin G, Altinas O, Karabas VL, Caglar Y, Almac A. Homocysteine levels in plasma and sensorineural hearing loss in patients with pseudoexfoliation syndrome. Eur J Ophthalmol. 2006;16(4):542-7.

6. Ritch R. Exfoliation syndrome - the most common identifiable cause of open-angle glaucoma. J Glaucoma. 1994;3:176-7.

7. Aasved H. The geographical distribution of fibrillopathia epitheliocapsularis, so-called senile exfoliation or pseudoexfoliation of the anterior lens capsule. Acta Ophthalmol.1969;47:792.

8. Astrom S, Linden C. Incidence and prevalence of pseudoexfoliation and open-angle glaucoma in northern Sweden: I Baseline report. Acta Ophthalmol Scand. 2007;85:828-31. http:// dx.doi.org/10.1111/j.1600-0420.2007.00992.x

9. Shafig I, Sharif-ul-Hasan K. Pseuooexfoliation (PEX) glaucoma over the age of 40 years; a hospital based study. Pak J Ophthalmol. 2007;4(23):221-7.

10. Jonas JB, Nangia V, Matin A, Bhojwanki K, Sinha A, Khare A, Agarwal S, Bhate K. Pseudoexfoliation: normative data and associations.The central India Eye and Medical Study. PLoS One. 2013;8(10):e76770. http://dx.doi.org/10.1371/journal. pone. 0076770

11. Arnarsson A, Damji KF, Sverrisson T, Sasaki H, Jonasson F. Pseudoexfoliation in the Reykjavik Eye Study: prevalence and related ophthalmological variables. Acta Ophthalmol Scand. 2007;85(8):822-7. http://dx.doi.org/10.1111/j.1600$-1420.2007 .01051 . x$

12. Kozobolis VP, Papatzanaki M, Vlachonikolis IG, Pallikaris IG, Tsambarlakis IG. Epidemiology of pseudoexfoliation in the island of Crete (Greece). Acta Ophthalmol Scand. 1997;75:726-9.

13. Bartholomew RS. Pseudocapsular exfoliation in the Bantu of South Africa. II Occurrence and prevalence. Br J Ophthalmol. 1973;57(1):41-5.

14. Vakil AA, Sajad S. The prevalence of pseudoexfoliation syndrome and pseudoexfoliation glaucoma in south Kashmir. J Med Sci. 2012;15(1):51-3.

15. Cumurcu T, Kilic R, Yologlu S. The frequency of pseudoexfoliation syndrome in the middle Black Sea region of Turkey. Eur J Ophthalmol. 2010;20(6):1007-11.

16. Kaljurand K, Teesalu P. Prevalence of exfoliation syndrome in Estonia. Eur J Ophthalmol. 2010;20(6):1012-7.

17. Viso E, Rodrigez-Ares MT, Gude F. Prevalence of pseudoexfoliation syndrome among adult Spanish in the Salnes Eye Study. Ophthalmic Epidemiol. 2010;17(2):118-24. http://dx.doi. org/10.3109/09286581003624970

18. Ritch R. Exfoliation syndrome: clinical findings and occurrence in patients with occludable angles. Trans Am Ophthalmol Soc. 1994;92:845-944.

19. Susić N, Brajković J. The prevalence of pseudoexfoliation syndrome in patients admitted for cataract surgery to the Department of Ophthalmology, Šibenik General Hospital. Acta Med Croatica. 2006;60(2):121-4.

20. Drolsum L, Ringvold A, Nicolaissen B. Cataract and glaucoma surgery in pseudoexfoliation syndrome: a review. Acta Ophthalmol Scand. 2007;85(8):810-21. 
21. Scorolli L, Scorolli L, Campos EC, Bassein L, Meduri RA. Pseudoexfoliation syndrome: a cohort study on intraoperative complications in cataract surgery. Ophthalmologica. 1998; 212:278-80.

22. Chen M, Lamattina KC, Patrianakos T, Dwarakanathan S. Complication rate of posterior capsular rupture with vitreous loss during phacoemulsification at a Hawaiian cataract surgical center: a clinical audit. Clin Ophthalmol. 2014;5(8):375-8. http://dx.doi.org/10.2147/OPTH.S57736

23. Krepste L, Kuzmiene L, Miliauskas A, Januleviciene I. Possible predisposing factors for late intraocular lens dislocation after routine cataract surgery. Medicina. 2013;49(5):229-34.

24. Shingleton BJ, Yang Y, O'Donoghue MW. Management and outcomes of intraocular lens dislocation in patients with pseudoexfoliation. J Cataract Refract Surg. 2013;39(7):984-93. http://dx.doi.org/10.1016/j.jcrs.2013.01.044

25. Hohn S, Spraul CW, Buchwald HJ, Lang GK. Spontaneous dislocation of intraocular lens with capsule as a late complication of cataract surgery in patients with pseudoexfoliation syndrome - five case reports. Klin Monatbl Augenheilkd. 2004; 221(4):273-6. http;//dx.doi.org/10.1055/s-2014-813000

26. Le A, Mukesh BN, McCarty CA, Taylor HR. Risk factors associated with the incidence of open-angle glaucoma: the visual impairment project. Invest Ophthalmol Vis Sci. 2003;44:3783-9.

27. Leske MC,Wu S-Y, Hennis A, Honkanen R, Nemesure B, BES Study Group. Risk factors for incident open-angle glaucoma. The Barbados Eye Studies. Ophthalmology. 2008;115: 85-93. http://dx.doi.org/10.1016/j.ophtha.2007.03.017

28. Ekstrom C. Risk factors for incident open-angle glaucoma: a population-based 20-year follow up study. Acta Ophthalmol. 2012;90(4):316-21. http://dx.doi.org/10.1111/j.1755. 3768.2010.01943.x

29. Vesti E, Kivela T. Exfoliation syndrome and exfoliation glaucoma. Prog Retin Eye Res. 2000;19(3):345-68.

30. Gramer G, Weber BH, Gramer E. Results of a patient-directed survey on frequency of family history of glaucoma in $2170 \mathrm{pa}^{-}$ tients. Invest Ophthalmol Vis Sci. 2014;55(1):259-64. http:// dx.doi.org/10.1167/iovs.13-13020

31. Szaflik JP, Cuchra M, Przybylowska-Sygut K, Dziki L, Kurowska AK, Gacek M, Drzewoski J, Szaflik J, Majsterek I. Association of the 399Arg/Gln XRCC1, the $194 \mathrm{Arg} /$ Trp XRCC1, the 326Ser/Cys OGG1, and the 324Gln/His MUTYH gene polymorphisms of primary open-angle glaucoma. Mutat Res. 2013;753(1):12-22.

32. Tielsch JM, Sommer A, Katz J, et al. Racial variations in the prevalence of primary open-angle glaucoma. The Baltimore Eye Survey. JAMA. 1991;266:369-74.
33. Kosoko-Lasaki O, Gong G, Haynatzki G, Wilson MR. Race, ethnicity and prevalence of primary open-angle glaucoma. J Natl Med Assoc. 2006;98(10):1626-9.

34. Dark AJ, Streeten BW. Precapsular film on the aging human lens: precursor of pseudoexfoliation? Br J Ophthalmol. 1990; 74(12):712-22.

35. Dielemans I, Vingerling JR, Wolfs RCW, Hofman A, Grobbee $\mathrm{DE}$, et al. The prevalence of primary open angle glaucoma in a population-based study in The Netherlands. The Rotterdam study. Ophthalmology. 1994;11(101):1851-5.

36. Rudnicka AR, Mt-Isa S, Owen CG, Cook DG, Ashby D. Variations in primary open- angle glaucoma prevalence by age, gender, and race: a Bayesian meta analysis. Invest Ophthalmol Vis Sci. 2006;10(47):4254-61. http://dx.doi.org/10.1167/ iovs.06-0299

37. George R, Paul PG, Baskaran M, Ve Ramesh S, Raju P, Arvind $\mathrm{H}$, et al. Ocular biometry in occludable angles and angle closure glaucoma: a population based survey. Br J Ophthalmol. 2003; 87:399-402.

38. Seah SK, Foster PJ, Chew PT, Jap A, Oen F, Fam HB, Lim AS. Incidence of acute primary angle-closure glaucoma in Singapore. An island-wide survey. Arch Ophthalmol. 1997;115 (11):1436-40.

39. Bojić L, Rogošić V, Kovačić Z, Kljajić Z, Poljak NK, Hrgović Z. Incidence of acute angle-closure attacks in Split-Dalmatia County, Croatia. Acta Clin Croat. 2012;51(3):397-401.

40. Bojić L, Mandić Z, Ivanišević M, Bućan K, Kovačević S, Gverović A, Miletić-Jurić A. Incidence of acute angle-closure glaucoma in Dalmatia, southern Croatia. Croat Med J. 2004; 45(3):279-82.

41. Congdon N, Wang F, Tielsch JM. Issues in the epidemiology and population based screening of primary angle-closure glaucoma. Surv Ophthalmol. 1992;36(6):411-23.

42. Jonasson F, Damji KF, Arnarsson A, Sverrisson T, Wang L, Sasaki H, Sasaki K; the Reykjavik Eye Study Group. Prevalence of open-angle glaucoma in Iceland: Reykjavik Eye Study. Eye. 2003;17:747-53. http://dx.doi.org/10.1038/sj.eye.6700374

43. Kaimbo WA, Kaimbo D. Pseudoexfoliation syndrome in Congolese patients. J Fran Ophthalmol. 2012;35(1):40-5. http:// dx.doi.org/10.1016/j.jfo.2011.04.018

44. Wertheimer-Baletić A. The demographic situation in the Croatian Republic. Lijec Vjesn. 1991;113(5-6):108-11.

45. Quigley HA, Broman AT. The number of people with glaucoma worldwide in 2010 and 2020. Br J Ophthalmol. 2006; 90(3):262-7. http://dx.doi.org/10.1136/bjo.2005.081224 
Sažetak

\title{
UČESTALOST PSEUDOEKSFOLIJATIVNOG SINDROMA I PSEUDOEKSFOLIJATIVNOG GLAUKOMA U POPULACIJI SJEVEROZAPADNE HRVATSKE U DOBI OD 40 GODINA I VIŠE
}

\author{
J. Pavičić-Astaloš, A. Koluder, L. Knežević, M. Zorić Geber, K. Novak Lauš, T. Csik, T. Knežević i M. Milošević
}

Svrha ovoga istraživanja bila je procijeniti učestalost pseudoeksfolijativnog sindroma i pseudoeksfolijativnog glaukoma te njihovu povezanost s glaukomom otvorenog kuta kod bolesnika Očne poliklinike Opće bolnice "Dr. Tomislav Bardek" u Koprivnici, sjeverozapadna Hrvatska. Ovo prospektivno istraživanje provedeno je od prosinca 2012. do listopada 2013. godine. Ukupno je pregledano 5349 ispitanika u dobi od 40 godina i više. Kod svakog je učinjen kompletan oftalmološki pregled uključujući anamnezu, ispitivanje vidne oštrine, pregled na biomikroskopu, aplanacijsku tonometriju, pregled očnoga živca i pozadine oka te vidno polje i gonioskopiju kod onih sa sumnjom na glaukom. Kriteriji za isključenje bili su bolesnici s pseudofakijom/afakijom, bolesnici s prirođenim očnim bolestima te oni s vrlo gustim zamućenjem očnih medija. Od 5349 bolesnika bilo je 1994 (38,38\%) muškaraca i 3201 (61,61\%) žena. Učestalost pseudoeksfolijativnog sindroma bila je 3,6\%, a primarnog glaukoma otvorenog kuta 9,4\%, od čega 23,6\% spada u skupinu pseudoeksfolijativnog glaukoma. Rezultati ove studije proširuju naše spoznaje o pseudoeksfolijativnom sindromu i pseudoeksfolijativnom glaukomu u Hrvatskoj, osobito u sjeverozapadnoj regiji.

Ključne riječi: Eksfolijacijski sindrom - epidemiologija; Učestalost; Starija osoba; Glaukom 